原著 心尖部肥大型心筋症の体表面電位分布の

\title{
特徵と定量的評価
}

\begin{tabular}{|c|c|c|c|c|c|}
\hline & & 名古剭大学 & 部第一个 & & \\
\hline 林 & 博史っ* & 石川 富久 & 上松 & 治儀 & 小島 \\
\hline 稲垣 & 春夫 & 河合 㥀樹 & 外畑 & 崺 & \\
\hline
\end{tabular}

\section{BODY SURFACE POTENTIAL DISTRIBUTION IN APICAL HYPERTROPHY OF IDIOPATHIC CARDIOMYOPATHY AND ITS QUANTITATIVE EVALUATION}

Hiroshi Hayashi, MD, Tomihisa Ishikawa, MD, Haruyoshi Uematsu, MD, Haruki KorIma, MD,

Haruo INAGAKI, MD, Naoki KawaI, MD and Iwao SoTobata, MD

The First Department of Internal Medicine, Nagoya University, School of Medicine, Nagoya

\begin{abstract}
概要 心尖部肥大型心筋症の体表面電位図を記録し，その電位分布の特徵を明らかにするとと もに，定量的評価を試みた，心エュー困，心葴カテーテル法などで診断した肥大型心筋症のう ち， ${ }^{201} \mathrm{~T}$ 摄取指数が心尖部において特に高く，心尖部肥大型心管定之判定されたAPH群19例を 対象とした。年令は22才から63才，平均44.5才で，全例男性であつた，対照として，律康成人 ( $\mathrm{N}$ 群) 43例（平均年令28.9才）を用いた。電位図は，85点の誘導点からの単極誘導心電図から マイクロコンピューター内䁍の電位図記録装置で記録した. APH群のR波の最大値は，左鎖骨 中線上の第 4 ・第 5 肋間括よび左前夜窝線上の第 4 肋間にあり，N群のそれと同じであつた。 $\mathrm{S}$ 波の最大值を示す誘導点もAPH群とN群の間で差がなからた。しかし，APH群の招の拈のの 電位はN群に比して著しく大きからた。巨大陰性 T波の分布は，最大 $\mathrm{R}$ 波の分布領域とほば致した。最大正電位に達するむでの時間(peak voltage time)は, APH群は平均 $43.5 \pm 8.5 \mathrm{msec}$, $\mathrm{N}$ 群は平均36.2土6.5msecで, 前者が有意に延長していた $(\mathrm{P}<0.05)$. 'niche'の出現時間は, $\mathrm{APH}$ 群は平均 $34.4 \pm 7.8 \mathrm{msec}, \mathrm{N}$ 群は平均 $27.0 \pm 4.5 \mathrm{msec}$ で, 前者が有意に遅延した（P< $0.01) . \Sigma S\left(V_{1}, E_{5}, F_{5}\right.$ 誘導の $S$ 波の和) 括よび $\Sigma R\left(G_{3}, G_{4}, H_{4}\right.$ 誘導のR波の和) + $\mathrm{SS}$ (同 上），心尖部領域の ${ }^{201} \mathrm{Tl}$ 掑取指数との間に扣のおの正の相関関係を有した．我々の設定した 体表面の心尖部領域に，極大が停滞する時間（apical activation time）は，心尖部 ${ }^{201} \mathrm{Tl}$ 摂取 指数との間任正の相関関係を有した。
\end{abstract}

はじめに

特発性心筋症 (ICM) のうち, 肥大型心筋症 (HCM) の中には，心筋全体が肥厚しているもの と，種々の心筇部位が特に限局性に肥厚している ものがあることが，手術中の観察あるいは剖検に

[昭和56年 9 月 24 日受稿】

*. 名古屋大学附属病院中央検查部
より，確認されている。これらの肥厚の部位と程 度を臨床的に推定する方法としては，心蔵カテー テル法による左室造影，心ェコー図あるいは，RI 心筋シンチグラフィー, RI心プールスキャン等が ある。これらはいずれる心蔵の解剖学的構策を, 形態学的に評価する方法であり，その有用性は広 く認められている.

一方，心電図怙よびベクトル電図はICMのこれ 
ら特異な解剖学的特徵に基因する電気現象を把え ることにより，その異常を判定しょうとするもの である.

しかし，これらの方法は心筋の局所的な電気現 象を拾い上げるのには，大きな制約があり，その 診断能力は必ずしも十分とはいえない，体表面心 臓電位図 (電位図) は，この制約をある程度解決 するものである゙2).

我々は先に電位図のこの特質を利用して, ICM の中隔肥大例の定性的, 定量的評価を心エコ一図, 剖検から得られた結果と対比して行ない, 電位図 の有用性を認めた ${ }^{3)}$.

最近, ICMの中に, 心室中隔下方から心尖部に かけての部位が他の部位に比して著しく肥大して いる例のあることが, 左室造影法4), 左右心室同時 造影法 ${ }^{51}$, 超音波猃断法6)などにより明らかにされ ている。

今回はICMのうち心尖部に特異な肥大を示す 例について, その電位分布の特徵を検討し，その 定量的評価を試みた。

\section{対象並びに方法}

対象は, 肥大型心筋症のうち, ${ }^{201} \mathrm{Tl}$ 心筋シンチ
グラフィーにより，心尖部の摂取指数が増加して おり，既報の診断基準7)で判定した心尖部肥大型 心筋症 (APH群) 19例であつた。 これは全例男性

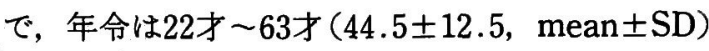
であつた。

ICMの診断は, 病歴, 身体所見, 心電図, ベク トル心電図, 胸部写真, 心ェコー図, 心蔵カテー テル法等により行なわれ，高血圧，弁膜症，その 他心肥大を来す基礎疾患の合併のあるものは除外 した（図 1，2）。

なお，対照群（N群）として健康成人43例（男 性25例, 女性18例, 年令20才〜61才，平均 28.9 才） を用いた。

方法は，体表面上85点 (胸部59点, 背部26点) からの単極誘導心電困を同時記録し，中日電子製 マイクロコンピューター内缄mapper HPM 5100 により電位図を作成した8).

得られた電位図より，各誘導点が有する最大正 電位 ( $\mathrm{R}$ 波)，最大負電位（ $\mathrm{S}$ 波）扣よび，再分極 期の最大負電位 (陰性 $\mathrm{T}$ 波), 最大正電位 (陽性 $\mathrm{T}$ 波)を求めた。

また, $\mathrm{APH}$ 群および，N群間に括ける各誘導点

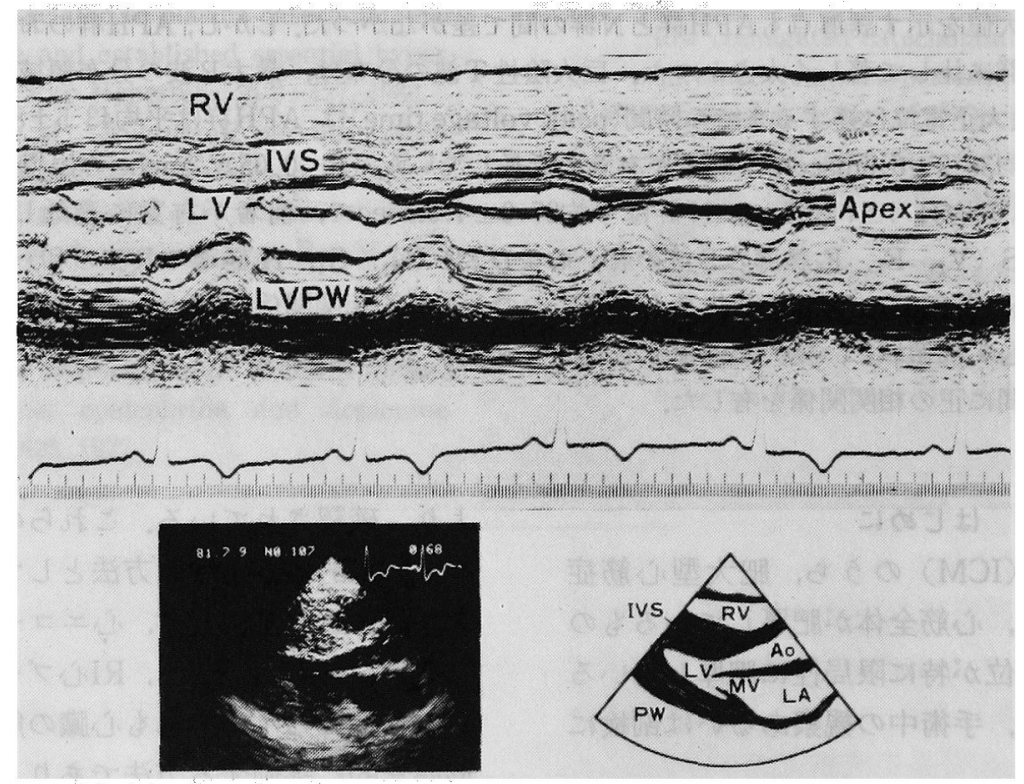

図 1。心尖部肥大型心筋症 (APH) のMモード心ェュー図と超音波断層図 (T.Y. 55 才, 男). 中隔, 左室後壁共に心尖部方向で厚さを増大している. 

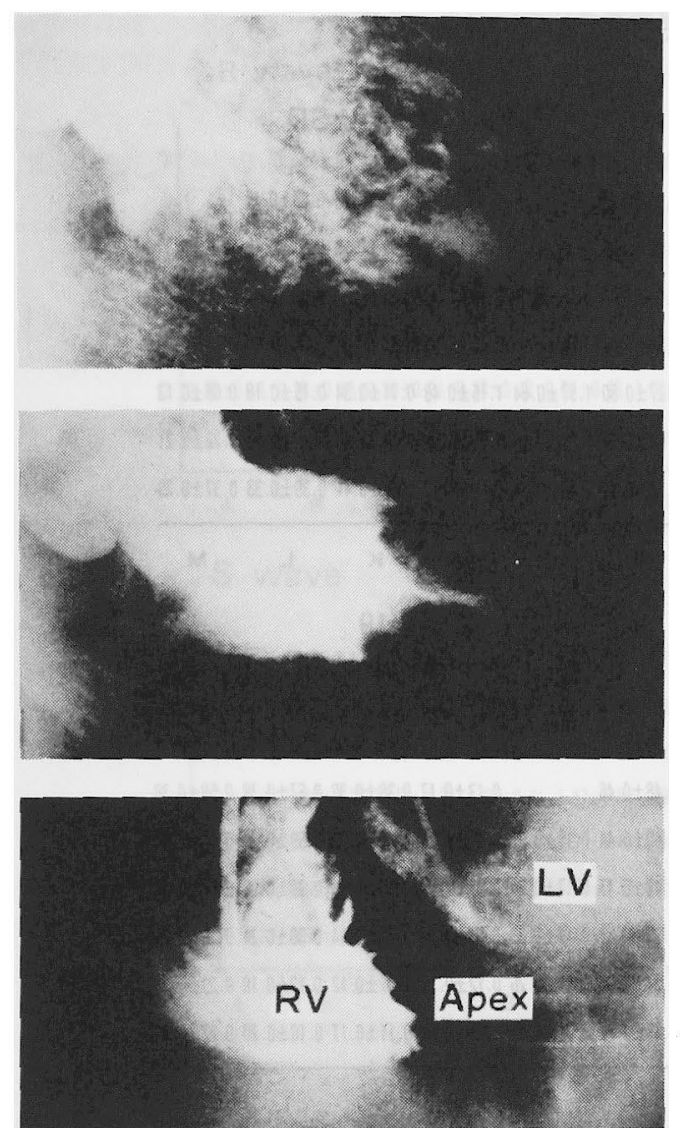

図 2.心尖部肥大例の左室造影（上：払張期, 中： 収縮期) と両室造影 (下) 所見 (K.K、54才, 男)。心 尖部肥大のため収縮終期に，心尖部の先細りが著明で ある. 両室造影により中隔が明らかに認められ, 心尖 部肥大が確診された。

のR波と S 波高の有意差の検定を行なつた.

心室脱分極期における極大（最大正電位）の体 表面上の経時的な移動を検討し, 左鎖骨中線, 左 前腋窩線上に極大が存在する時間帯をAPH群, N 群について求め心尖部興奮時間とした。

${ }^{201} \mathrm{Tl}$ 心筋シンチグラフィーは, ${ }^{201} \mathrm{TlCl}$ 用いて 正面, 左前斜位 $30^{\circ}, 45^{\circ}, 60^{\circ}$, 左側面の像を得た.

心筋シンチグラフィーでは，心筋部分に九つの 関心領域（ROI）を設定し, 綖隔洞領域のbackground countに対する各ROI countの比，すなわ ち ${ }^{201} \mathrm{~T}$ l摂取指数 (MUI) を求めた。これにより既 報の診断基準》に従つて, 心尖部のMUIが特異的
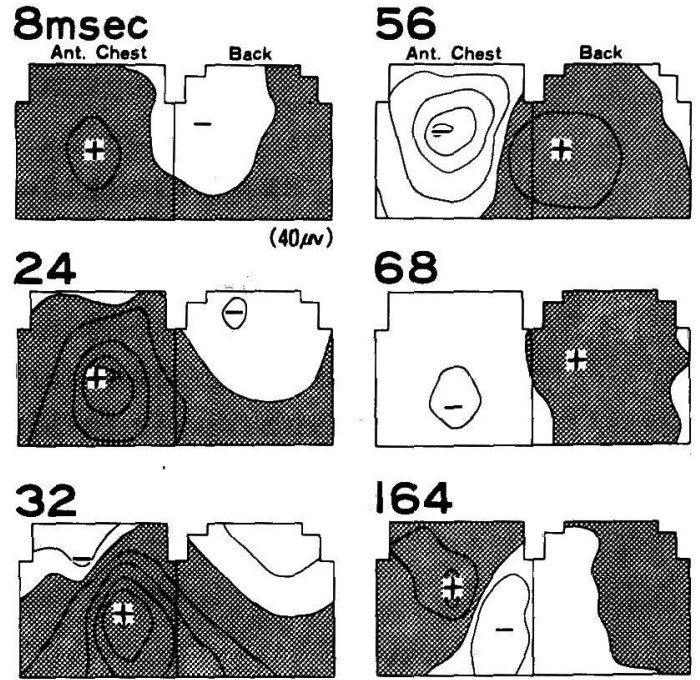

164
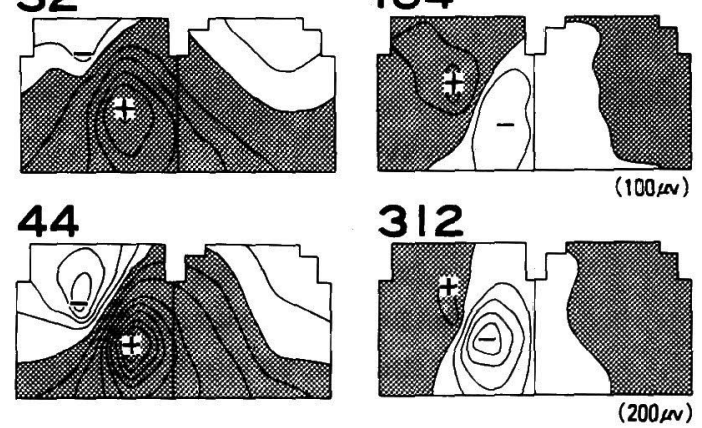

図 3.APHの電位図の経時的変化. 興奮伝播過程は正 常とほぼ同様であるが, nicheの出現時間がやや遅く (32msec)，心尖部の極大電位が著しく大きい(44 $\mathrm{msec}$ ). また, 極大が, 左鎖骨中線, 左前腋窩線に留る 時間が長い(各フレームの左半分は前胸部, 右半分は 背部を示す. 等電位線は, $\mathrm{QRS} 40 \mu \mathrm{V}$ 毎, STは $100 \mu \mathrm{V}$ 毎, $\mathrm{T} は 200 \mu \mathrm{V}$ 毎).

に高い例を，心尖部肥大型心筋症 $(\mathrm{APH})$ とした。 結果

APH群の 1 例の電位図を図 3 に示す。室興奮 は, 正常と同様に中隔を左室側から右室側へと進 展して開始する（8，24msec），その後いわゆる niche（正・負領域の境界の零線の陥凹）が出現し $(32 \mathrm{msec})$, 興奮は次第に左室前壁から心尖部に進 展するが (44msec), 心尖部における電位は 3.3 $\mathrm{mV}$ と著しく高く, 極大も長時間この周辺に停滞 した。興奮はさらに側壁から後壁へと進み(56, $68 \mathrm{msec})$ 興奮を終了して興奮回復過程が開始した (164msec).なお， T波の極期では，著しい負電位 (極小)が, $44 \mathrm{msec}$ における極大と同じ心尖部領域 に存在した (312msec).

1） APHのR波およびS波高の分布（表 1, 図 
表 1. APH群19例の各誘導点の R波, $\mathrm{S}$ 波高 $(\mathrm{mV})(m e a n \pm \mathrm{SD})$

R wave

\section{$0.16 \pm 0.240 .08 \pm 0.14$}

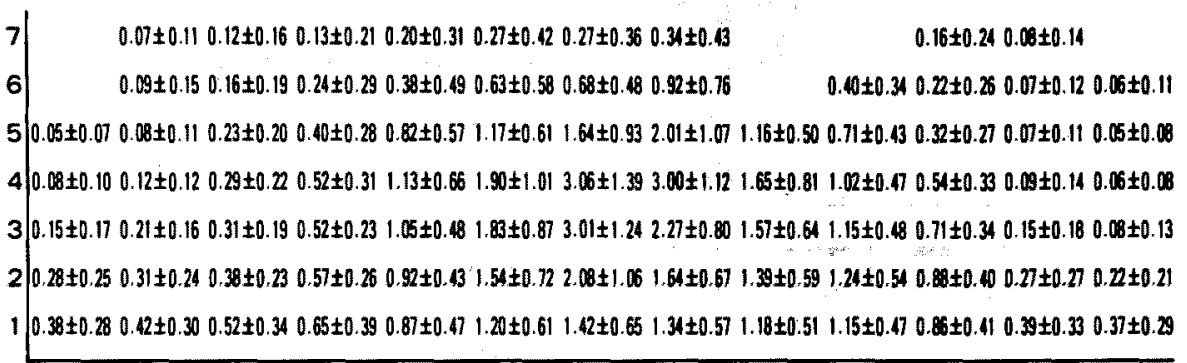

\section{S wave}
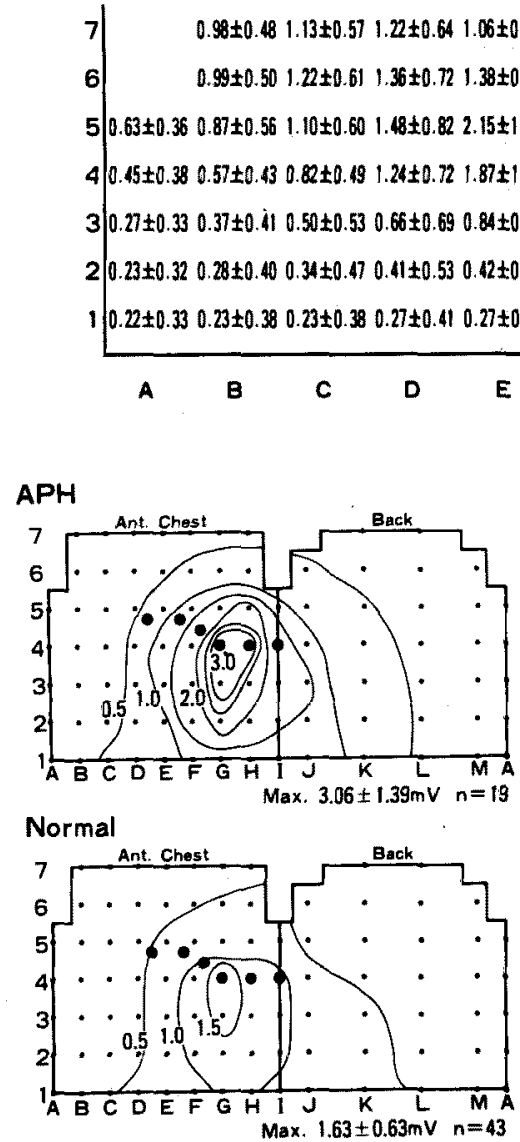

因 4.APH群とN群の各誘導点の R 波高の平均値， ᄀ レーム中の点は，85誘導点，六つの黒丸は標準12誘導 心電図の $V_{1}-V_{6}$ の位置. 等電位線は $0.5 \mathrm{mV}$ 毎に引い てある.

$$
n=19
$$

Mean \pm SD

$\begin{array}{llllllllllllll}\text { A } & \text { B } & \text { C } & \text { D } & \text { E } & \text { F } & G & H & \text { I } & J & K & L & M\end{array}$

$$
n=19
$$

\section{Mean \pm SD}

$0.45 \pm 0.200 .72 \pm 0.40$

$0.13 \pm 0.170 .38 \pm 0.300 .67 \pm 0.380 .58 \pm 0.38$ $0.210 .11 \pm 0.150 .32 \pm 0.230 .59 \pm 0.280 .54 \pm 0.37$ $0.240 .07 \pm 0.150 .18 \pm 0.180 .39 \pm 0.260 .44 \pm 0.28$ $0.230 .08 \pm 0.160 .08 \pm 0.140 .35 \pm 0.240 .30 \pm 0.25$

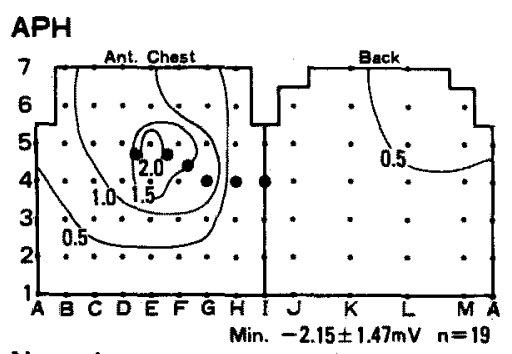

Normal

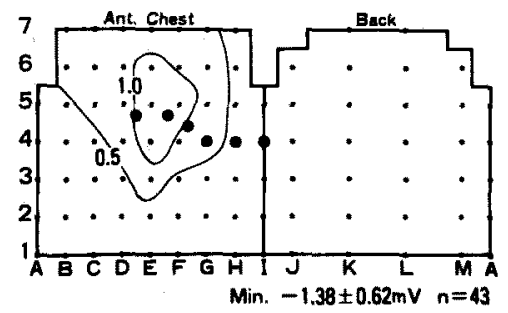

图 5.APH群とN群の各誘点点の $\mathrm{S}$ 波高の平均值. 
表 2、N群43例の各誘導点のR波， S 波高 $(\mathrm{mV})(\mathrm{mean} \pm \mathrm{SD})$

R wave

$\left(\begin{array}{l}N=43 \\ M E A N \pm S D\end{array}\right)$

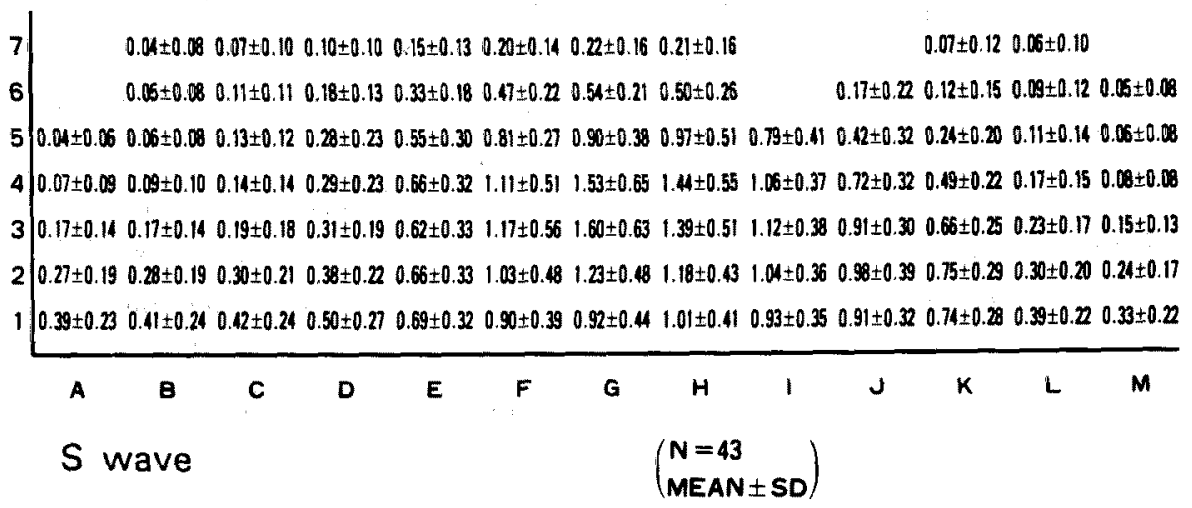

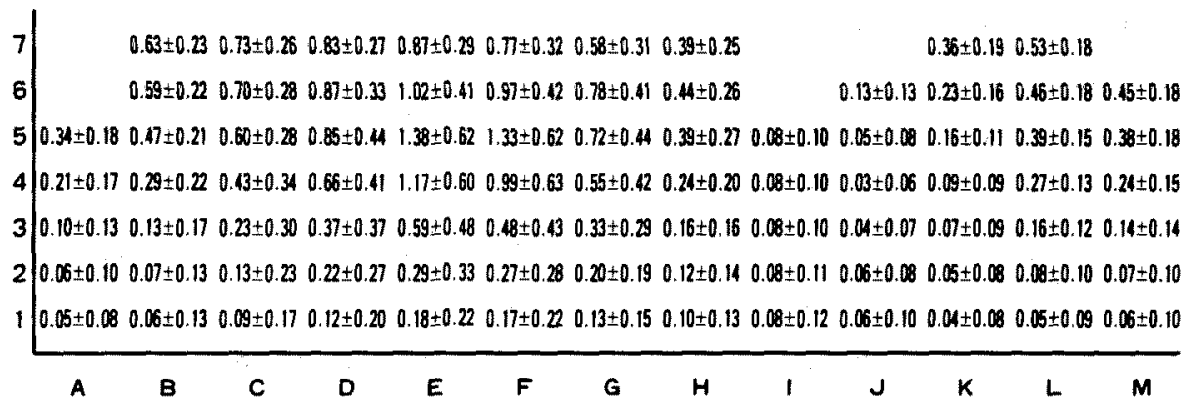

$4,5)$

$\mathrm{R}$ 波高が3mV以上の高值を示した誘導点は, $\mathrm{G} 4$ 扣よびG3，すなわち左鎖骨中線上第 5，6肋間牤 よびH4，すなわち左前腋窩線上第 5 助間であり，

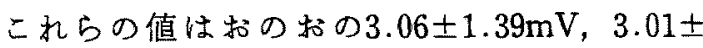
$1.24 \mathrm{mV}, 3.00 \pm 1.12 \mathrm{mV}$ であつた (mean $\pm \mathrm{SD}$, 以下同様).

これらを中心に高電位領域は，ほぼ同心円状に 拡がり，0.5mV領域はトルンー下方に向かつて拡 がつて分布した。

$\mathrm{S}$ 波高が最大值を示した誘導点は，E5すなわ ち，胸骨正中線上第 3 肋間に存在し，その值は $2.15 \pm 1.47 \mathrm{mV}$ だあった，高電位領域は，この点か ら右肩方向にやや偏心性に抎がり，0.5mV領域で は，前胸部の上半分のほ注全体を覆い右背部上方 にまで拡がつた。

2）正常のR波および 波高の分布（表 2 、図 4,5 )

R波高が最大值を示した誘導点はG3すなわち
左鎖骨中線上第 6 肋間であり，その值は 1.60 土 $0.63 \mathrm{mV}$ であった。高電位領域はこの点から左側 胸部下方に向かつて，やや偏心性に払がり，0.5 $\mathrm{mV}$ 領域はAPHのそれとほぼ同じであつた。

$\mathrm{S}$ 波高が最大值を示した誘導点は，E5すなるら 胸骨正中線上第 3 肋間に存在し，その值は1.38士 $0.62 \mathrm{mV}$ であつた. 高電位領域は，この点を中心に 前胸部上万に払がつた。

3） APH群とN群間のR波おょび 波高の差 (図 6)

APH群がN群に比して, 有意にR波高の増大を 示した領域は左前胸部を中心にして $(P<0.001)$ ほぼ同心円状に搪がり $(\mathrm{P}<0.01)$ ，さらに前胸部 下方拉よび左側胸部下方に及んだ $(\mathrm{P}<0.05)$.

一方, $\mathrm{APH}$ 群のS 波高がN群のそれに比して有 意に増大を示した領域は，右前胸部上方および右 背部上方 $(P<0.001)$ と，これらを囲む右前胸部 および背部下方の領域であつた（P<0.01および $\mathrm{P}<0.05)$. 

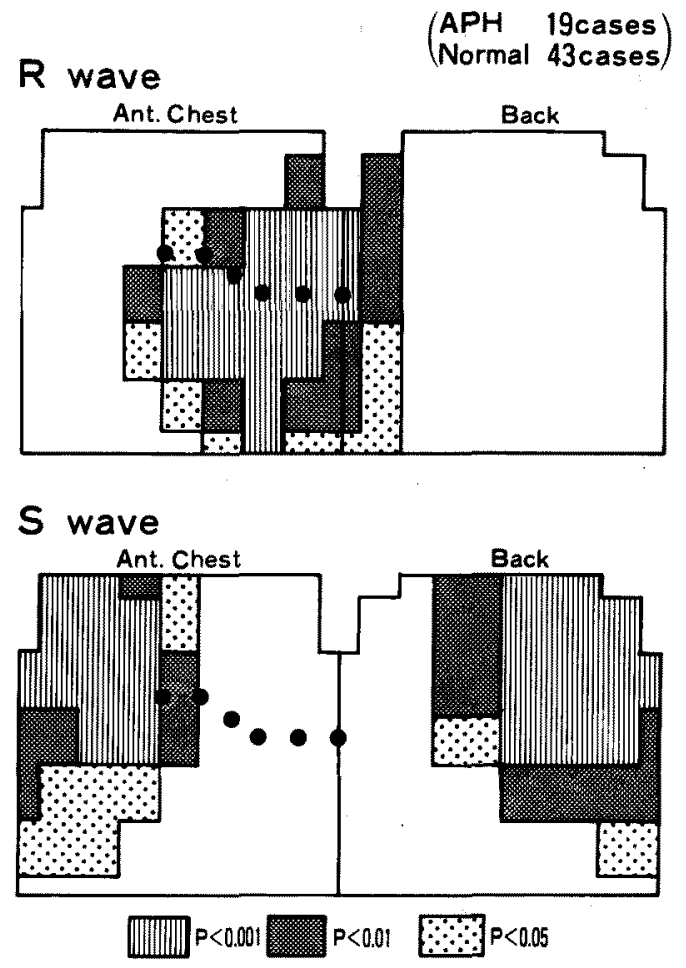

図 6. APH群とN群間の各誘導点のR波と $\mathrm{S}$ 波の大き さの有意差検定.

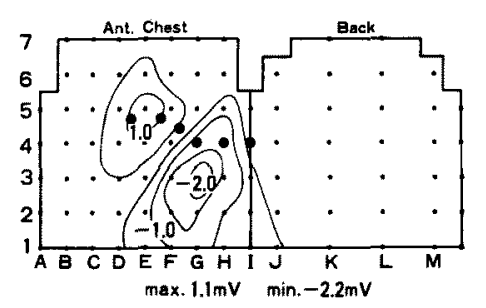

図 7. T波の正，負最大値の分布図 ( T max map) の 1 例. 等電位線は $0.5 \mathrm{mV}$ 毎に示してある。最大陰性抹 よび陽性 T波の位置は, おのおのR波，S波の最大值 を示す誘導点と同じである。

\section{4）陰性 T波の分布（図 7)}

陰性 T波が最大值を示寸誘道点の分布は, G4が 10例，G3が5例，F4とH4がおのおの 2 例であつ た. 陰性 $\mathrm{T}$ 波の最大值を示す誘導点は, 図 1 で示 した最大 R 波の誘導点 (G3，G4，H4) と一致する 例が多く, 陽性 T波が最大值を示す誘導点は, 最 大S波の誘導点（E4，E5，F5）に一致する例が多 かつた。

5） R波おょひ S 波高と心尖部 ${ }^{201} \mathrm{Tl}$ 摄取指数

\section{との相関}

$\mathrm{R}$ 波高に関しては心尖部 ${ }^{201} \mathrm{Tl}$ 摄取率と相関を 有する単一の誘導点は存在しなかつた。

一方, $\mathrm{S}$ 波高 $(\mathrm{y})$ と尖部 ${ }^{201} \mathrm{Tl}$ 摂取指数 $(\mathrm{x})$ とが有意の相関を有する誘導点は以下の 5 点であ つた.

i ）心電図 $V_{1}$ に相当する誘導点

$$
(\mathrm{y}=1.4 \mathrm{x}-0.7, \mathrm{r}=0.80)
$$

ii）胸骨正中線上第 3 肋間の誘導点 (E5)

$$
(y=2.34 x-1.77, r=0.73)
$$

iii）左傍胸骨線上第 3 肋間の誘導点 (F5)

$$
\begin{array}{r}
(y=1.17 x-1.00, r=0.74) \\
(\text { 以上 } P<0.01)
\end{array}
$$

iv）心電図 $V_{2}$ に相当する誘導点 $(r=0.66)$

v) 左鎖骨中線上第 2 助間の誘導点 (G6)

$$
(r=0.63)
$$

(以上 $P<0.05)$

相隣接する i ） ii） iii）の誘導点のS 波高の和， $\Sigma \mathrm{S}(\mathrm{mV})(\mathrm{y})$ と $^{201} \mathrm{~T} 1$ 摂取指数 $(\mathrm{x})$ の相関は次 の如くであつた（図 8).

$$
\mathrm{y}=4.4 \mathrm{x}-1.1 \quad(\mathrm{r}=0.65, \mathrm{P}<0.05)
$$

なお， $\mathrm{R}$ 波高が最も大きい 3 誘導点 $\mathrm{G} 3$, $\mathrm{G} 4\left(\mathrm{~V}_{4}\right) ， \mathrm{H} 4\left(\mathrm{~V}_{5}\right)$ のR波高の和， $\mathrm{sR}(\mathrm{mV})$ は ${ }^{201} \mathrm{Tl}$ 摄取指数と全く相関しなかつたが， $\Sigma \mathrm{R}+\Sigma \mathrm{S}$ （y）とは正相関を示した $(y=5.7 x+5.5, r=0.58$, $\mathrm{P}<0.05$ ) (図 8 ).

\section{6）心尖部興奮時間（apical activation time)}

心尖部興奮の開始時間は, $\mathrm{N}$ 群で21.1 msec, APH群は, 26.5 10.8msec (N S ), 終 了時間はN群 $44.7 \pm 7.5 \mathrm{msec}$, APH群 $57.1 \pm 10.2$

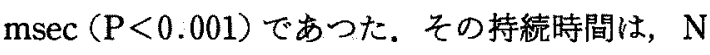

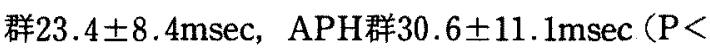
0.02)で, APH群に叔いて有意に延長がみられた。

な拉，心尖部興奮時間と心尖部 ${ }^{201} \mathrm{~T} 1$ 摄取指数と の関係を求めると, 心尖部における ${ }^{201} \mathrm{Tl}$ 摂取指数 (x) が高いもの程心尖部興奮時間 $(\mathrm{y})$ は延長す る傾向がみられ，両者には以下の関係が認められ た（図 9).

$$
y=13.2 x+9.1 \quad(r=0.68, \quad P<0.005) \text {. }
$$




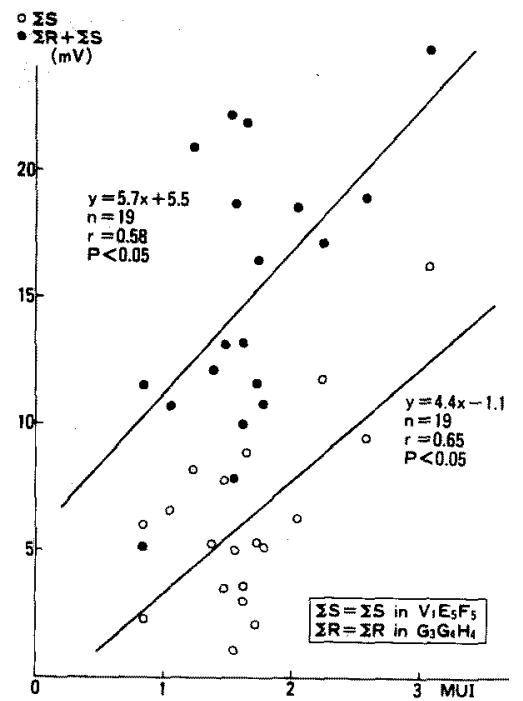

図 8.APHに和ける心矢部 ${ }^{201} \mathrm{TI}$ 摄取指数とこSおよび $\Sigma R+\Sigma S$ との関係.

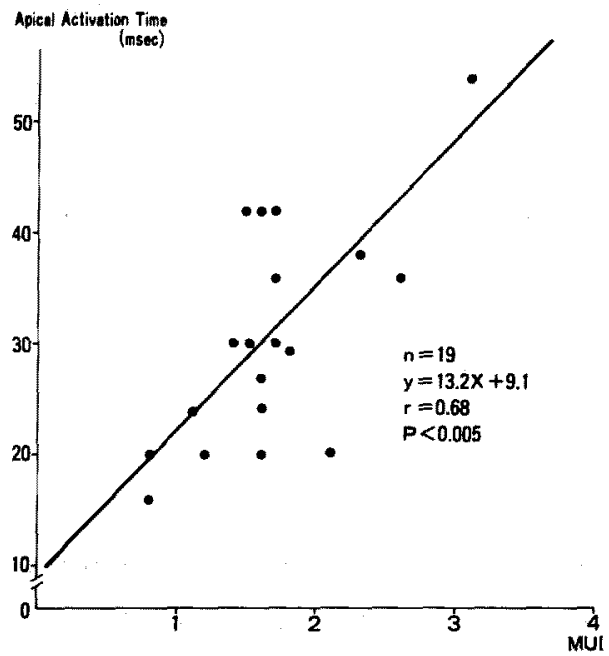

図 9.心尖部興鹤時間と ${ }^{201} \mathrm{~T}$ 摂取指数との相関\&係。

\section{7）最大正電位に達するまでの時間（peak voltage time)}

APH群のそれは，27msecから54msecで平均 43.5土8.5msecであり，N群は24msecから51msec で平均 $36.2 \pm 6.5 \mathrm{msec} て ゙$ 前者が有意に延長してい た $(\mathrm{P}<0.05)$.

\section{8） Nicheの出現時間とその部位}

APH群のnicheの出現時間は, $24 \mathrm{msec} か ら 48$

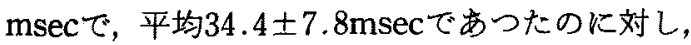

$\mathrm{N}$ 群では $18 \mathrm{msec}$ から $36 \mathrm{msec}$ 平均 $27.0 \pm 4.5 \mathrm{msec}$ で前者は有意に出現時間が遅れた $(\mathrm{P}<0.01)$. nicheの出現部位は, APH 群では, E4 7 例 (36.8\%), E5 4 例 (21.1\%), E6 3 例 (15.8\%), その他F5，D5が扮の执の 2 例 (10.5\%)，F4 1 例 (5.3\%)であつた。一方，N群ではE5 17例 (39.5\%), F5 7 例 (16.3\%), E4 5 例 (11.6\%),

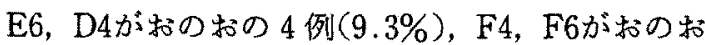
の 2 例 (4.7\%)，E7，D5が各 1例 (2.3\%)であつ た。すなわち，両群間にniche出現部位の差は認め ら礼なかつた。

\section{考案}

体表面電位図は，Wilson中心電極を基準とする 単極誘導心電図を体表面上の多数の点から記録 し，これをもとにして瞬時每の電位を等電位線で 結んで表現したものである、従つて，これによれ ば心蔵各部位の電気現象をある程度分離して理解 することができ，かつ，その経時的变化をる，把 握することが可能である(12).

これまで心筋硬塞, WPW症候群, 右脚プロック などは，電位図により種々の検討がなされてきた が, ICMに関する研究はまだ非常に少なく ${ }^{9)}$,今後 十分検討がなされねばならない。

APHでは, 著しく肥厚した心尖部に対心する体 表面に高電位領域が存在することが推定される。 Selvesterらは10)，シミュレーション法を用いて， 心藏を17個の区画に分けて，それぞれの興奮によ り体表面心電図上に如何なる電位が，どの領域に 反映されるかを検討した。 その結果，心尖部およ び中隔部分は体表面上に明確に投影されることを 示しており，その対応関係は，今回の我々の結果 とほぼ一致している。APH群に颃いて，R波高が 特に大きい誘導点は, G3, G4 $\left(V_{4}\right), \mathrm{H} 4\left(V_{5}\right)$ の 3点であったが，これらはN群に拈けるそれと全 く同じであつた．また，S波高が著しく大きい誘 導点はAPH群では, E4, E5, F5の 3 点であつたが, これらすN群のそれと全く同じであつた。これは APH群では，一般に心拡大を伴わないものが多い ため心尖部がN群に比して余り偏位せず，心臟の 回転も伴わないことにより説明でさるであろう。 
一方，先に行なつた我々の検討で大動脈升閉鎖 不全症など著しい心拡大を伴ら場合には， R波は 著しく増大すると共に，その最大值を示す誘導点 はN群あるいは，APH群に比して左下方すなわ ら，左前腋窩線上，第 5 肋間を中心に分布した ${ }^{11}$.

一方，R波，S波の最大值はAPH群ではN群に 比して著しく大きく，前述の各 3 誘導点を中心に して，ほぼ同心円状に高電位領域が桩がつた。

$\mathrm{R}$ 波高の0.5mV領域の払がりは, APH群, N群 との間でははとんど差が見られず, APH群が心尖 部を中心とした求心性肥大である事が示唆され た。 た $\mathrm{S}$ 波高の0.5mV領域の前胸部の拡がりも APH群はN群に比して，ひとまわり大きいが互い によく類似しており，心尖部における興奮前面の 見送り現象が，その程度こそ異にするが，は注同 様の領域に反映されたものと考えられる。

APH群のR波がN群に比して，有意に増大して いる誘導点は，注はAPH群に括ける R 波の $1 \mathrm{mV}$ 以上の領域之一致して括り，有意性の検定に括い て，その中心は危険率が小さく，辺縁はより危険 率が大きくなつた。

APH群の電位分布パターンでその他の特徽的 な事は，D，Eの 4，5領域 $\left(V_{1}, V_{2}\right.$ を含む領域 $)$ のR波高が極端に小さくなつたり，消失したりし ないことであつた，左室肥大が著しくなると， $V_{1}$ $\mathrm{V}_{2}$ のR波高が減少して，いわゆるpoor progressive Rを示し， septal forceが減少又は，消失する ことは，日常心電図又はべクトル心電図でしばし ば経験する ${ }^{12) 13)}$ 。これは, 左室自由壁の強大な興奮 による中隔興奮の相殺 (cancellation)によると考 えられ ${ }^{13)}$ ，中隔および左室自由壁における興奮の 前面の方向が互いにほぼ正反对になるために生ず る. APHでは, septal force とapical forceが互い に，正反対の方向ではなく，かつ，心尖部肥大は 中隔下方の肥大を伴らため, 起電力が相殺する状 況にないことによると考劣られる。

$\mathrm{APH}$ 群のS 波がN群に比して有意に増大を示 した誘導点は，胸部ではR 波高の場合と異なり， 最も高いS 波高を示した領域とは一致しておら ず，右肩から右前胸部上方を中心とした領域で，
右肩領域の方がより危険率が小さかつた，背部で はS 波高の0.5mV領域に一致した右上方により 危険率の小さい領域が存在した。

これらの所見む，APHは正常に扣ける起電力 が，全体的にほぼ均等に増大した求心性肥大であ ることを示唆するものであろう. ${ }^{201} \mathrm{~T} 1$ 撕取指数と APH群の各誘導点のR波括よびS波の大ささ之 の相関を求めた， ${ }^{201} \mathrm{Tl}$ 撕取指数は主として，心筋 潅流量に比例して増加すると考えられる14).これ までの検討では，左室容積（LV mass）は多くの 場合心エコー図から推定されていたが，今回は ${ }^{201} \mathrm{~T} 1$ 㩒取指数から局所心筋のmassを推定した。こ の方法は，特発性肥厚性弁下狭窄症 (IHSS) に招 いて有用であることが示されている15).

一方，心起電力の大きさは心筇の厚さ，あるい はその量と，拈よその比例関係のあることが，心 エコー图を用いた臨床的 ${ }^{16)}$ ，あるいはモデル実 験 ${ }^{17)}$ で認められているので, ${ }^{201} \mathrm{~T} 1$ 摄取指数と R 波 及びS波の大きさの間に相関が存在すると考兄ら れる。

G3, G4 $\left(V_{4}\right), H 4\left(V_{5}\right)$ の誘導点は心尖部に対 応すると考えられる体表面領域であり，その電位 も著しく大きかつた。この領域での高電位は，心 尖部肥大を示唆するむのではあつたが，この電位 の大きさと ${ }^{201} \mathrm{~T} l$ 摂取指数は比例せず，この電位の 大きさは心尖部肥大の程度を直接表現するもので はなかつた。

一方，図 8 で示した 5 誘導点のS 波の深さは, 心尖部 ${ }^{201} \mathrm{Tl}$ 摂取指数と正の相関関保を認めた。す なわち，心尖部が解剖学的に近接している体表面 領域の R 波電位が，心尖部肥大の程度を反映せず， いわばその電位の対側性変化とでもいらべき深い $\mathrm{S}$ 波が，前胸部上方すなわち，心の長軸に対して 心尖部と反対の領域にみられ，これが心尖肥大の 程度を半定量的に表現した。 この理由としては以 下のことが考えられた。すなわち，体表面上で高 いR波を生ずる因子としては，心肥大の他に心蔵 と誘導点までの距離が大きな影響を有する，心尖 部肥大では，心尖部が胸壁に非常に近く存在する ため，肥大そのるのより相対的に距離の因子がよ 
り大きな役割を果たし，その結果R波電位の大き さが，そのまま心尖部肥大の程度を表現しない結 果をもたらす。

この際，S 波電位と，心尖部 ${ }^{201} \mathrm{Tl}$ 摄取指数とが 高い相関を有する誘導点か，前胸部上方から左肩 にかけて 5 点存在したが、これらのうちの1点か ら心尖部 ${ }^{201} \mathrm{~T} 1$ 摄取指数を推定するよりは数点の 電位の和からの推定の方が，各症例毎のバリエー ショソによる愦差をより小さくできる可能性があ る.

今回は, $V_{1}, E 5, F 5 の 3$ 誘導点か $5 \Sigma S$ 求め, ${ }^{201}$ T1摄取指数との相関を求め，注注満足できる結果 を認めた。

ICMでは, APHに限らず, 左室肥大ストレイン を示寸例が非常に多い。

APHに括いて左胸部誘導の R 波高電位と同時 に観察される深い陰性 T波は, ventricular gradientの方向が正常範围から大き逸脱しており，こ の場合のT波変化は一次性といわれる6).

今回の19例の $\mathrm{APH}$ 群の T波の電位分布の検討 によれば，巨大陰性T波のピークは，G4，G3に最 も多く存在し，これらの領域は， R波のピークの 位置と同じであつた。

従つて, APHにみられる巨大陰性 $\mathrm{T}$ 波の成因と して著しい心筋肥大に伴う心外膜側の再分極の遅 延あるいは, 心尖部と心基部の壁厚の著しい差が， 再分極過程に異常をきたしていることも考えら れ，二次性変化すある程度関与している可能性が 示唆された。

肥大型閉塞性心筋症に括いて，中隔肥大がある と中隔興奮に要する時間が延長することが認めら れている(19).我々も中隔肥大型心筋症において, 中 隔心起電力をよく反映する領域に，電位図上の極 大が正常に比して著しく長時間停滞することを報 告した3).

同様に, APH群において，最大 R電位が記録さ れることから心尖部の電位をよく反映すると考兄 られるG，H線，すなわち左鎖骨中線，左前腋窩線 上に極大が停滞する時間は，正常に比して著しく 長いことを認めた。これは，肥大のために興奮に
要する時間が延長したためであり左室肥大心電図 において，左胸部誘導の心室興奮時間 (ventricular activation time) の延長が認められることと 類似の現象と考えられる。事実，我々は各誘導点 において，最大正電位に達するまでの時間を求め， 等時線表示した“peak time map”を各種心疾患に ついて作成したが，心肥大あるいは，脚ブロック では興奮伝播時間が延長し，isochrone line(等時 線)の密集を認めている20).

ICMの中で左室肥大所見は $60 \%$ 以上の高率に みられるが37/38)，その原因としては，対称性肥大に よるむのと非対称性肥大によるむのがあり，さら に扮の扮のが払大を伴ら例などがある。非対称性 肥大では，従来より中隔肥大が大きくとりあげら れてきたが，心尖部肥大の存在も問題となろう。 同じ左室高電位を示す心䇨症であつても，このよ うに種々の病態の違いがあり臨床的意義も大いに 異なる. 今後, 求心性肥大をもたらす高血圧心や， 大動脈升狭窄症など圧負荷疾患に抢ける電位分布 を検討し，APHとの差を検討する必要がある。電 位図により高電位の分布パターンの違いから肥大 様式の差を推定し，さらにその領域の電位の大き さから，肥大心笳の半定量的診断まで可能となれ ば，電位図は非漫襲的診断法として極めて，優れ た方法として評価され，患者の管理，治療に大い に貢献すると考えられる。

\section{結 論}

心尖部肥大型心筋症 (APH群) 19例の体表面心 蔵電位図を記録し，健常者（N群）43例のそれと 対比して，以下の結論を得た。

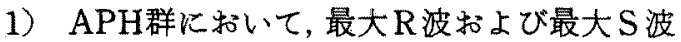
の電位は，N群のそれに比して著しく大きかつた が，これらの誘導点の位置は，N群のそれと汪注 同じであつた。

2）巨大陰性 $\mathrm{T}$ 波の分布領域は，最大 $\mathrm{R}$ 波のそ れとほぼ一致した。

3）最大正電位に達するまでの時間（peak voltage time)は, APH群は, 平均 $43.5 \pm 8.5 \mathrm{msec}$

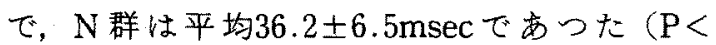
$0.05)$. 
4) 'niche'の出現時間は, APH群は平均34.4土

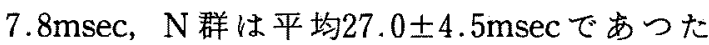
$(\mathrm{P}<0.01)$.

5） $\Sigma S$ 执よび $\Sigma R+\Sigma S は ，$ 特のおの心尖部領域の ${ }^{201} \mathrm{Tl}$ 摄取指数との間に，正の相関々係を有した $(\mathrm{P}<0.05, \mathrm{P}<0.05)$.

6）体表面上の心尖部領域に，極大が停滞する 時間 (apical activation time) は，心尖部 ${ }^{201} \mathrm{Tl}$ 摂 取指数との間に，正相関を認めた $(\mathrm{P}<0.005)$.

謝辞 図 2 の心室造影図は浜松西部医療センター，西嶋憲 治先生，藤原千冬先生の御厚意によるるのであり深謝しま I.

\section{文 献}

1) Horan LG, et al: Body surface potential distribution: Comparison of naturally and artificially produced signals as analyzed by digital computer. Circul Res $13: 373,1963$.

2) Abildskov JA, et al: Experimental evidence for regional cardiac influence in body surface isopotential maps of dogs. Circul Res $38: 386$, 1976.

3）石川富久，他：体表面心葴電位図に上る中隔肥大 の定性的扩よび定量的評価。呼吸之循環 29 ： $545,1981$.

4) Yamaguchi $\mathrm{H}$, et al: Hypertrophic cardiomyopathy with giant negative T-clinical and angiographic characteristics. Jap Circul J 40 : $514,1976$.

5) Redwood DR, et al: Biventricular cineangiography in the evaluation of patients with asymmetric septal hypertrophy. Circulation 49 : 1116, 1974.

6) Sakamoto $T$, et al: Giant $T$ wave inversion as a manifestation of asymmetrical apical hypertrophy $(\mathrm{AAH})$ of the left ventricle. Echocardiographic and ultrasono-cardiotomographic study. Jap Heart J 17 : 611, 1976.

7) Watanabe $Y$, et al: The quantitative diagnosis of Thallium-201 myocardial perfusion images and vectorcardiograms in myocardial infarction and hypertrophic cardiomyopathy. Jap Circul J 45 : 148, 1981.
8) Hayashi $\mathrm{H}$, et al : Diagnostic value of body surface map in myocardial infarction. Assessment of location, size and ejection fraction as compared with coronary cineangiography and ${ }^{201} \mathrm{~T} 1$ myocardial scintigraphy. Jap Circul J $44: 197,1980$.

9) Flowers NC and Horan LG: Comparative surface potential patterns in obstructive and nonobstructive cardiomyopathy. Am Heart J $86: 196,1973$.

10) Selvester RH, et al: Propagation velocities and voltage magnitudes in local segments of myocardium. Circul Res 27:619, 1970.

11）石川富久，他：大動脈弁閉鎖不全症における体表 面上R波扣上びS波の診断的意義。呼吸と循環 30 : (9 月号)，1982.

12) Selzer A, et al: Electrocardiographic findings in concentric and eccentric left ventricular hypertrophy. Amer Heart J 63: 320, 1962.

13) Wallace $A G$, et al: The vectorcardiogram in left ventricular hypertrophy. A study using the Frank lead system. Amer Heart J 63 : 466, 1962.

14) Sapirstein LA : Regional blood flow by fractional distribution of indicators. Amer J Physiol $193: 161,1958$.

15) Bulkley $\mathrm{BH}$, et al: Idiopathic hypertrophic subaortic stenosis: Detection by thallium 201 myocardial perfusion imaging. New Engl J Med 293: 1113, 1975.

16) Toshima $\mathrm{H}$, et al : Correlations between electrocardiographic, vectorcardiographic, and echocardiographic findings in patients with left ventricular overload. Amer Heart J $94: 547$, 1977.

17) Mashima, S: Theoretical considerations on the electrocardiogram of ventricular hypertrophy. J Electrocardiol $9: 133,1976$.

18) Jacobson D and Schrire V: Giant $T$ wave inversion. Brit Heart J 28: 768, 1966.

19) Van Dam RT, et al: Electrical activation of ventricles and interventricular septum in hy. pertrophic obstructive cardiomyopathy. Brit Heart J 34: 100, 1972.

20）林 博史，他：体表面心隇電位図からみ心心室興 熖伝播過程. 日本臨床 $39: 217,1981$. 